\title{
Corruption of Regional Heads in Indonesia; Anatomy, Causative Factors, And Solutions
}

\author{
H Agustina ${ }^{1}$, A Sutarih ${ }^{2}$ \\ $\left\{\underline{\text { heryaniagustina28@gmail.com }}{ }^{1}\right\}$ \\ ${ }^{1,2}$ Universitas Swadaya Gunung JatiCirebon, Indonesia
}

\begin{abstract}
The new era of regional autonomy in Indonesia not only caused decentralization of governance from the center to the regions but also caused 'decentralization' corruption from the center to the regions. Throughout 20042018, the Corruption Eradication Commission (KPK) has conducted sting operations (OTT) against 104 regional heads in 23 provinces. Many factors are the causes of regional head corruption, both concerning the individual characteristics of regional heads and those related to regulations, systems and the environment. Various efforts have been made to tackle and eradicate corruption, but regional heads seem to have never been deterred from committing corruption. To prevent and eradicate corruption in regional heads, it is necessary to enforce strict and indiscriminate law enforcement and very heavy sanctions that provide a deterrent effect.
\end{abstract}

Keywords: corruption, regional head, bureaucratic reform

\section{Introduction}

The reform era in Indonesia which began to roll out since the fall of the New Order regime on May 21, 1998 has caused several significant changes in the life of the nation and state. One of them is the birth of a new era of regional autonomy which was marked by the enactment of Law Number 22 of 1999 concerning Regional Government. The law has changed the paradigm of administering regional government from centralized to decentralized and has given enormous power and authority to regional heads so that they become 'small kings' in the region.

In its journey, Law Number 22 Year 1999 was later changed to Law Number 32 of 2004, which was later amended to become Law Number 23 of 2014. However, these changes still gave a large amount of power and authority to the regional head. While Law No. 32 of 2004 also provides a new milestone in regional elections because since the enactment of the law, regional elections (Pilkada) since 2005 have been directly elected by the people, so the election results are more legitimate compared to elections by Regional People's Representative Assembly (DPRD) such as previous.

A new era of regional autonomy provided fresh air in the implementation of the regional government. However, based on the evaluation of LIPI (2007) and UNDP (2008), regional autonomy in Indonesia showed more failure than its success. One of the biggest failures was that regional autonomy not only caused decentralization of governance from the center to the regions but also caused 'decentralization' corruption from the center to the regions. This was indicated by a large number of regional heads who were caught in corruption cases. ICW at the end of December 2018 which had released during 2004-2018 recorded 104 regional heads 
caught in the hands of the KPK[1]. This is very ironic because the head of the region should be the main driving force in improving people's welfare which is both the goal and the spirit of regional autonomy.

\section{Discussion}

\subsection{Anatomy of Regional Heads Corruption in Indonesia}

According to Webster's Third New International Dictionary [2], corruption is an invitation (from a public official) with improper considerations for committing a violation of duty. An action can be categorized as an act of corruption if it contains the following elements the presence of the perpetrator or several perpetrators; any action that violates the prevailing norms, both moral / religious, ethical, or legal aspects; the existence of an element of detrimental to the financial or wealth of the state or society, both directly and indirectly; the existence of an element obtains a personal gain or a certain group.

While the World Bank defines corruption as an abuse of public authority to obtain personal benefits (the abuse of public office for private gain) ". Whereas according to Robert Klitgaard, corruption exists if someone illegally puts personal interests above the interests of the community and something entrusted to him to be carried out. Corruption appears in various forms and varies from small to monumental. Corruption can involve abuse of policy tools[2].

According to Law Number 31 of 1999 concerning Eradication of Corruption Crimes which has been amended by Law Number 20 of 2001 in Article 2 Paragraph 1 it is stated that criminal acts of corruption are acts "Anyone who violates the law by enriching himself or others or a corporation that can harm the country's finances or the country's economy. " Whereas in Article 3, it is stated that criminal acts of corruption are carried out by "Every person who aims to benefit himself or another person or corporation, misuses the authority, opportunity or means thereof because of his position and position which can harm the state or the country's economy"[3].

Law No. 31 of 1999 concerning the Eradication of Corruption Crime was born at the beginning of the reform era to overcome the rampant corruption during the new order which led to the fall of the Suharto regime. Furthermore, to make corruption eradication effective, then in 2002 based on Law Number 30 of 2002 a Corruption Crime Eradication Commission was established or better known as the Corruption Eradication Commission (KPK) [3].

During the 2004-2018 period, the KPK has carried out Sting Operations (OTT) against 104 regional heads, with details as follows:

Table 1. Regional Heads Caught in KPK Sting Operations (OTT) in 2004-2018

\begin{tabular}{cccc}
\hline No. & Year & Number of OTT & Percentage \\
\hline $\mathbf{1 .}$ & 2004 & 1 & $1,0 \%$ \\
\hline $\mathbf{2 .}$ & 2005 & 1 & $1,0 \%$ \\
\hline $\mathbf{3 .}$ & 2006 & 4 & $3,8 \%$ \\
\hline $\mathbf{4 .}$ & 2007 & 7 & $6,7 \%$ \\
\hline $\mathbf{5 .}$ & 2008 & 6 & $5,8 \%$ \\
\hline $\mathbf{6 .}$ & 2009 & 6 & $5,8 \%$ \\
\hline $\mathbf{7 .}$ & 2010 & 4 & $3,8 \%$ \\
\hline $\mathbf{8 .}$ & 2011 & 3 & $2,9 \%$ \\
\hline $\mathbf{9 .}$ & 2012 & 4 & $3,8 \%$ \\
\hline
\end{tabular}




\begin{tabular}{cccc}
\hline $\mathbf{1 0 .}$ & 2013 & 4 & $3,8 \%$ \\
\hline $\mathbf{1 1}$ & 2014 & 14 & $13,5 \%$ \\
\hline $\mathbf{1 2 .}$ & 2015 & 4 & $3,8 \%$ \\
\hline $\mathbf{1 3 .}$ & 2016 & 9 & $8,7 \%$ \\
\hline $\mathbf{1 4 .}$ & 2017 & 8 & $7,7 \%$ \\
\hline $\mathbf{1 5 .}$ & 2018 & 29 & $27,9 \%$ \\
\hline & Total & $\mathbf{1 0 4}$ & $\mathbf{1 0 0 , 0} \%$
\end{tabular}

Source: www.tribunnews.com (processed data), 2018[4]

Based on the data above, the heads of regions caught by the KPK Sting Operations (OTT) during 2004-2018 fluctuated, but the most cases were in 2018, namely 29 regional heads, followed in 2014 by 14 regional heads. Position of regional head caught by KPK Sting Operations (OTT) during 2004-2018 was:

Table 2. Position of Regional Head

Caught by the KPK Sting Operations (OTT) in 2004-2018

\begin{tabular}{clcc}
\hline No. & \multicolumn{1}{c}{ Position } & Number of OTT & Percentage \\
\hline 1. & Governor & 15 & $14,4 \%$ \\
\hline 2. & Mayor & 23 & $22,1 \%$ \\
\hline 3. & Regent & 62 & $59,6 \%$ \\
\hline 4. & Vice Mayor & 1 & $1,0 \%$ \\
\hline 5. & Vice Regent & 3 & $2,9 \%$ \\
\hline \multicolumn{2}{r}{ Total } & $\mathbf{1 0 4}$ & $\mathbf{1 0 0 , 0} \%$ \\
\hline
\end{tabular}

Source: www.tribunnews.com (processed data), 2018[4]

Based on the data above, during 2004-2018, the regional heads who were caught by the KPK Sting Operations (OTT) were the Regents (62 people) then the Mayor (23 people), the Governor (15 people), the Vice Regent (3 people), and the least were Vice Mayor (1 person). The heads of regions caught by the KPK OTT by province are:

Table 3. Regional Head Caught by KPK Sting Operations (OTT) In 2004-2018 Based on Province

\begin{tabular}{clcc}
\hline No. & \multicolumn{1}{c}{ Province } & Number of OTT & Percentage \\
\hline 1. & East Java & 14 & $13,5 \%$ \\
\hline 2. & North Sumatera & 12 & $11,5 \%$ \\
\hline 3. & West Java & 11 & $10,6 \%$ \\
\hline 4. & Central Java & 8 & $7,7 \%$ \\
\hline 5. & Southeast Sulawesi & 6 & $5,8 \%$ \\
\hline 6. & Papua & 5 & $4,8 \%$ \\
\hline 7. & Riau & 5 & $4,8 \%$ \\
\hline 8. & Nangroe Aceh Darusallam & 4 & $3,8 \%$ \\
\hline 9. & Banten & 4 & $3,8 \%$ \\
\hline 10. & East Kalimantan & 4 & $3,8 \%$ \\
\hline 11. & South Sumatera & 4 & $3,8 \%$ \\
\hline 12. & Bengkulu & 3 & $2,9 \%$ \\
\hline 13. & Lampung & 3 & $2,9 \%$ \\
\hline
\end{tabular}




\begin{tabular}{llcc}
\hline 14. & North Maluku & 3 & $2,9 \%$ \\
\hline 15. & West Nusa Tenggara & 3 & $2,9 \%$ \\
\hline 16. & South Sulawesi & 3 & $2,9 \%$ \\
\hline 17. & North Sulawesi & 3 & $2,9 \%$ \\
\hline $\mathbf{1 8}$. & South Kalimantan & 2 & $1,9 \%$ \\
\hline $\mathbf{1 9}$. & Riau Islands & 2 & $1,9 \%$ \\
\hline 20. & East Nusa Tenggara & 2 & $1,9 \%$ \\
\hline 21. & Jambi & 1 & $1,0 \%$ \\
\hline $\mathbf{2 2}$. & Central Kalimantan & 1 & $1,0 \%$ \\
\hline $\mathbf{2 3}$. & Central Sulawesi & 1 & $1,0 \%$ \\
\hline & Total & $\mathbf{1 0 4}$ & $\mathbf{1 0 0 , 0} \%$ \\
\hline
\end{tabular}

Source: www.merdeka.com (processed data), 2018[1]

Based on the data above, regional heads caught by the KPK Sting Operations (OTT) during 2004-2018 were spread in 23 provinces of 34 provinces in Indonesia. The provinces with the most regional heads caught by the KPK Sting Operations (OTT) are East Java (14 people), North Sumatra (12 people), and West Java (11 people). Only 11 provinces whose regional heads did not catch by the KPK Sting Operations (OTT), they are West Sumatra, Bangka Belitung Islands, DKI Jakarta, DI Yogyakarta, Bali, North Kalimantan, West Kalimantan, Gorontalo, West Sulawesi, Maluku, and West Papua.

Modus of corruption actions carried out by regional heads include mark up of the budget and various gratuities (bribery). The gratuities that have been carried out are in the management of permits, bidding/bidding processes, projects, and promotion.

\subsection{Factors Causing Corruption of Regional Heads}

Regional head corruption in Indonesia is caused by several interrelated factors, namely:

\section{Expensive election costs}

Before the direct elections in 2005, the number of regional heads caught by the KPK Sting Operation (OTT) was relatively small, it was only 1 person in 2004 and 2005. However, after the direct local election, the number of regional heads caught by KPK Sting Operation (OTT) increased and the peak occurred in 2018 as many as 29 people. The question is whether there is a correlation between direct regional elections and the number of regional heads caught by the KPK Sting Operation (OTT)?

The Vice President of the KPK, Alexander Marwata, said that the KPK had conducted a study of the Regional Election funding related to several OTTs carried out by the KPK. After the investigation was carried out, many regional heads caught by OTT said that they participated in the elections by being sponsored by certain parties or even borrowing money. Some said that to become regional heads had to prepare Rp. 20-30 billion, even in Java it was bigger than that. Even if it is calculated from the official income of the regional head for 5 years it does not reach Rp. 6 billion. As a result, the elected regional heads will attempt to return the money spent at the time of the elections. The high cost of political costs makes it difficult to eradicate corruption[5].

Political costs are the main weakness indirect regional elections. This has been predicted by Amirudin \& Bisri[6] that regional election in the era of political liberalization allows once those who can fight in regional elections are those who have strong economic and political 
capital. According to Rusli [7], most of the corrupt practices of regional heads are due to the high political dowry that regional head candidates must pay to political parties that carry them.

The cost of regional elections is expensive too because many regional head candidates do money politics in the form of distributing money to constituents to get as many votes as possible. The practice of money politics becomes a culture in Indonesian politics. The constituents whose welfare level is less will make their choice to the regional head candidates who give the most money. If the basis is money, then the direct local election will not produce a competent regional head, but a corrupt regional head to return all the costs of the elections that have been issued.

\section{Big regional head power and weak integrity}

Corruption is also closely related to the type of patrimonial bureaucracy adopted in Indonesia as a legacy of the royal bureaucracy of the past. In the patrimonial bureaucracy, the king was very powerful because ownership of economic resources rested with the king[8]. The regional head in the era of regional autonomy is like a 'little king' in his area but has great power.

Lord Acton (1834-1902) said that "Power tends to be corrupt and absolute power corrupts absolutely." Lord Acton's statement more than a century ago was proven by the rampant corruption cases of regional heads in Indonesia. Although the power of the regional head is not absolute because of limited laws, his great power is not accompanied by integrity, so many regional heads who abuse their power to enrich themselves by means of corruption. The regional government whose report obtains WTP (Unqualified opinion) from the Audit Board of the Republic of Indonesia (BPK) also does not guarantee that the regional head is free from corruption. This is because the WTPs are only based on financial statements, while the corruption of the regional head is related to the personal integrity of the regional head concerned.

\section{The practice of corruption that has been entrenched}

Corruption is strongly influenced by the environment and the system in which a community lives[9]. The Indonesian government environment and the bureaucratic system has been contaminated by the corruption virus for a long time so that acts of corruption are considered normal. This condition is compounded by a permissive attitude towards violations, irregularities, and abuse of authority.

In addition, corruption is also triggered by the existence of a pervasive mentality, namely a passionate mentality to achieve its goals as quickly as possible without much willingness to try from the beginning step by step[10]. In this case, the head of the region was eager to get a 'return on investment' to pay for the election costs that had been issued. This mentality is in line with the assumption of the rational choice approach, that individuals make choices with the aim of pursuing personal interests[11].

\section{Weak law enforcement}

According to Law Number 20 Year 2001 concerning Amendment to Law Number 31 of 1999 concerning Eradication of Corruption in Article 11 it is affirmed that "Imprisoned with a minimum of 1 (one) year imprisonment and a maximum of 5 (five) years and or a criminal fine of at least Rp. 50,000,000.00 (fifty million rupiahs) and a maximum of Rp. $250,000,000.00$ (two hundred fifty million rupiahs) civil servants or state administrators who 
receive gifts or promises even though it is known or reasonably suspected that the gift or promise is given because of the power or authority associated with his position, or in the mind of the person who gave the gift or promise there is a relationship with his position ".

Thus, the punishment for regional heads as the organizing of countries that commit corruption is relatively mild, imprisonment between 1-5 years and/or a fine of between $\mathrm{Rp}$. 50 million - Rp. 250 million. The sentence did not give a deterrent effect to the heads of other regions so that regional head corruption continued. Even while in prison, corruption convicts can still enjoy luxurious facilities by paying a sum of money to officers. The light prison sentence will also be lighter because they get remission every year.

\section{Bureaucratic reform is not optimal}

In the framework of bureaucratic reform, Presidential Regulation Number 81 of 2010[12] concerning Grand Design of Bureaucratic Reform 2010-2025 has been stipulated. The Grand Design is then translated into the 2010-2014 and 2015-2019 bureaucracy reform road map. In the grand design and road map of the bureaucratic reform, three targets for bureaucratic reform in Indonesia were established, namely the realization of clean and free of Corruption, Collusion, Nepotism (KKN) governance, increased quality of public services to the community, and increased capacity and accountability of bureaucratic performance.

The process of bureaucratic reform must be carried out seriously on four goals, they are concerning systems, policies, legislation, and moral character[13]. However, bureaucratic reform has only been limited to the skin: systems, policies and regulations, but it has not touched the contents of moral and moral. While the mental revolution movement launched by President Jokowi in December 2014 has lost its echo by the rampant corruption of regional heads precisely in the era of mental revolution.

\section{The weak function of the Regional People's Representative Assembly (DPRD) supervision and social control}

According to Law Number 23 Year 2014[14] concerning Regional Government, the Regional People's Representative Assembly (DPRD) has three functions, namely the establishment of Regional Regulations, budgets, and supervision. The supervisory function is manifested in the form of supervision of the implementation of local regulations and regional head regulations, implementation of the provisions of other laws and regulations related to the implementation of regional government, and the implementation of follow-up results of audit of financial statements by the Audit Board of the Republic of Indonesia (BPK). Therefore, the Regional People's Representative Assembly (DPRD) should be able to take part in preventing regional heads from committing corruption. However, the implementation of the Regional People's Representative Assembly's (DPRD) functions has not been optimal as seen from the many regional heads who committed corruption.

On the other hand, social control from the community is also weak because the community individually or organization (NGO) lacks or does not even have access to participate in overseeing the running of the regional government. Likewise, the press and media are known as the fourth pillar of democracy after the legislative, executive and judicial institutions. The press and media in the reform era were far more free than in the New Order era, but many press and media became instruments of power so that it was impossible to exercise effective social control over the authorities. While social control from the public through social media is also not optimal. People are afraid to report corruption because they are worried that they will 
be exposed to an article of insult or defamation based on the Electronic Information and Transaction Law (ITE).

\subsection{Solution to Prevention and Eradication of Corruption by Regional Heads in Indonesia}

Corruption is a bureaucratic disease that must be fought to its roots[15]. It is undeniable, the Indonesian government has made various efforts to eradicate corruption, among others by establishing regulations in the form of Number 31 of 1999 concerning the Eradication of Corruption Crimes which has been amended by Law Number 20 of 2001. In addition, in 2002 a Corruption Eradication Commission (KPK) was formed.

Eradication of corruption is also carried out through bureaucratic reform. According to Presidential Regulation Number 81 of 2010[12], bureaucratic reform is carried out using four methods, namely:

1. Preemptive; predict the possibility of bureaucratic practices that are seen as inefficient, ineffective, give rise to a long process, open opportunities for corruption, collusion, nepotism (KKN), and take anticipatory steps.

2. Persuasive; carry out various bureaucratic reform efforts such as socializing, public campaign, internalization, and building individual awareness and commitment.

3. Preventive; preventing the possibility of bureaucratic practices that are seen as inefficient, ineffective, giving rise to a long process, opening opportunities for KKN, and others, through changes in the mindset and culture set.

4. Actions / sanctions; apply sanctions or punishment for those who do not perform in the implementation of bureaucratic reform.

These various efforts have revealed the results where Indonesia's Corruption Perception Index (CPI) in 2017 showed a positive trend in terms of eradicating corruption. This can be seen from the increase in Indonesia's ranking from 32nd position in 2012 to 37th in 2017[16]. But on the other hand, these various efforts are not effective enough to prevent corruption in the regional head. The regional heads did not seem to be afraid of committing corruption even though many previous regional heads were caught by the KPK Sting Operation (OTT).

In addition, the government has enacted Law Number 1 of 2015[17] concerning the Establishment of Government Regulations as replacement of Law Number 1 of 2014 concerning the Election of Governors, Regents, and Mayors to Act. In Article 47 paragraph (1) it is affirmed that "Political Parties or a combination of Political Parties are prohibited from receiving compensation in any form in the process of nominating Governors, Regents, and Mayors". Then in paragraph (2) it is affirmed that "In the event that a Political Party or a combination of Political Parties is proven to receive compensation as referred to in paragraph (1), the Political Party or the combination of the Political Party concerned is prohibited from submitting candidates for the next period in the same area". In paragraph (5) it is affirmed that "Every person or institution is prohibited from giving compensation to Political Parties or any combination of Political Parties in any form in the process of nominating Governors, Regents, and Mayors". But in practice, the rewards as political dowry to political parties are still carried out, of course, carried out secretly.

According to the author, an effective solution to prevent regional head corruption is by means of strict law enforcement and not being selective. As is known, corruption in addition to terrorism and drugs is an extraordinary crime, so the eradication must also be carried out in extraordinary ways to provide a deterrent effect. The regional head who commits corruption must be punished with the greatest weight coupled with the seizure of property, the abolition 
of political rights, and if necessary must be punished by death. This death sentence is possible in Article 2 of Law Number 31 of 1999 concerning Eradication of Corruption Crimes[3].

\section{Conclusion}

In eradicating corruption, the Indonesian government must learn from China. The communist state was very strict in eradicating corruption, even imposing the death penalty for corruptors indiscriminately. This condition is in contrast to Indonesia. In addition, direct regional elections that are costly need to be evaluated because this is where the roots of regional head corruption begin.

If the cost of direct regional elections continues to cost a lot, then whenever the corruption of the regional head will continue to recur because the regional head must return all costs incurred during the regional election. In this case, there are some groups who have the idea to restore regional head elections by the Regional People's Representative Assembly (DPRD), even though this idea is a setback in the democratization process in Indonesia. In addition, if the penalties for regional heads who commit corruption are still mild, it will not provide a deterrent effect so that the corruption of regional heads will continue. In this case, of course, a strong commitment and especially courage is needed from the Indonesian government.

\section{References}

[1] N. Habibie, "Data 2004-2018: 104 Kepala Daerah Tersandung Korupsi, Paling Banyak di Jawa Timur," Merdeka.com. [Online]. Available: https://www.merdeka.com/peristiwa/data-2004-2018-104-kepala-daerah-tersandungkorupsi-paling-banyak-di-jawa-timur.html.

[2] S. Said and N. Suhendra, "Korupsi dan Masyarakat Indonesia," in Mencuri Uang Rakyat: Kajian Korupsi di Indonesia Buku 1, H. Basyaib, Ed. Jakarta: Yayasan Aksara, 2002.

[3] Presiden Republik Indonesia, Undang-Undang Nomor 31 Tahun 1999 tentang Pemberantasan Tindak Pidana Korupsi. 1999.

[4] F. Chrysnha and Palupi, "Data ICW: 104 Kepala Daerah Terjerat Korupsi, Sebanyak 29 Orang di Tahun 2018," Tribunnews.com. [Online]. Available: https://www.tribunnews.com/section/2018/12.

[5] H. Fadhil, "100 Kepala Daerah Terjerat Korupsi, KPK Bicara Biaya Politik Mahal," Detik. [Online]. Available: https://news.detik.com/berita/4273465/100-kepala-daerahterjerat-korupsi-kpk-bicara-biaya-politik-mahal.

[6] Amirudin and A. Z. Bisri, Pilkada Langsung. Problem dan Prospek. Yogyakarta: Pustaka Pelajar, 2006.

[7] B. Rusli, Isu-isu Krusial Administrasi Publik Kontemporer. Bandung: Mega Rancage, 2015.

[8] P. B. Santoso, Birokrasi Pemerintah Orde Baru: Perspektif Kultural dan Struktural. Jakarta: Raja Grafindo Persada, 1995.

[9] M. D. Rahardjo, "Korupsi, Kolusi, dan Nepotisme: Kajian Konseptual dan SosioKultural," in Menyingkap Korupsi, Kolusi, dan Nepotisme di Indonesia, E. S. Hamid and M. Sayuti, Eds. Yogyakarta: Aditya Media, 1999.

[10] Koentjaraningrat, Kebudayaan, Mentalitas dan Pembangunan. Jakarta: PT. Gramedia Pustaka Utama, 2015.

[11] M. Mas'oed, "Memahami Tantangan Reformasi Birokrasi," in Menyoal Birokrasi Publik, M. Thoha and A. Dharma, Eds. Jakarta: Balai Pustaka, 1999. 
[12] Presiden Republik Indonesia, Peraturan Presiden Nomor 81 Tahun 2010 tentang Grand Design Reformasi Birokrasi 2010-2025. 2010.

[13] F. Tamin, Reformasi Birokrasi: Analisis Pendayagunaan Aparatur Negara. Jakarta: Blantika, 2004.

[14] Presiden Republik Indonesia, Undang-Undang Nomor 23 Tahun 2014 tentang Pemerintahan Daerah. 2014.

[15] S. P. Siagian, Patologi Birokrasi. Jakarta: Ghalia Indonesia, 1994.

[16] Y. Kaka, "Berantas Korupsi: Belajarlah dari China," Kumparan. [Online]. Available: https://kumparan.com/yulius-kaka/berantas-korupsi-belajarlah-dari-china.

[17] Presiden Republik Indonesia, Undang-Undang Nomor 1 Tahun 2015 tentang Penetapan Peraturan Pemerintah Pengganti Undang-Undang Nomor 1 Tahun 2014 tentang Pemilihan Gubernur, Bupati dan Walikota Menjadi Undang-Undang. 2015. 